\title{
Biosorption of Heavy Metals from Aqueous Industrial Effluent by Non-living Biomass of Two Marine Green Algae Ulva lactuca and Dunaliella salina as Biosorpents
}

\author{
Jelan Mofeed* \\ Department of Aquatic Environment, Faculty of Fish Resources, Suez University, Egypt
}

\begin{abstract}
The growing industries in Suez Gulf lead to two serious environmental problems, heavy metals pollution, and eutrophication. The present work focused on, how those two problems can solve each other. Therefore, non-living dried biomass of the most blooming algae, "Ulva lactuca and Dunaliella salina" in Suez Gulf were used as biosorpents to remove heavy metals ( $\mathrm{Zn}, \mathrm{Cu}, \mathrm{Cd}, \mathrm{Fe}, \mathrm{Mn}, \mathrm{Pb}, \mathrm{Ni}$ and $\mathrm{Cr}$ ) from two types of aqueous industrial effluents, belonging to petrochemicals (E.1) and fertilizers (E.2) production. The results clarify that Biosorption capacity of D. salina was more powerful for $\mathrm{Cd}, \mathrm{Zn}$ and $\mathrm{Pb}$ within E.1, especially in case of lead $\left(22.34 \mathrm{mg} . \mathrm{g}^{-1}\right)$ showing distinct gap with E.2 (7.63 mg. $\left.\mathrm{g}^{-1}\right)$. However, U. lactuca was more efficient for Fe (4.07- $\left.15.86 \mathrm{mg} . \mathrm{g}^{-1}\right)$ and Cu (0.83- $\left.11.49 \mathrm{mg} \cdot \mathrm{g}^{-1}\right)$ within E.1, meanwhile it gave its maximum (2.75- $\left.10.9 \mathrm{mg} . \mathrm{g}^{-1}\right)$ within E.2 with significant capacity in case of $\mathrm{Mn}$. On the other hand, anent the removal efficiencies, $\mathrm{Cu}, \mathrm{Fe}$ and $\mathrm{Mn}$ had maximum removal efficiencies by $U$. lactuca within both effluents $(91.8,87.2$ and $84.8 \%$ respectively) with a superiority of E.2. However, in case of $\mathrm{Zn}(87.4 \%), \mathrm{Pb}(86.2 \%)$ and $\mathrm{Cd}(81.5 \%)$, $D$. salina was most efficiency. In conclusion, this work confirms the potential use of $U$. lactuca for removal of $\mathrm{Cu}, \mathrm{Fe}$, and $\mathrm{Mn}$, however, D. salina was more powerful in removing $\mathrm{Cd}, \mathrm{Zn}$, and $\mathrm{Pb}$ from industrial wastewater.
\end{abstract}

Keywords: Biosorption, heavy metals, industrial waste, Ulva lactuca Dunaliella salina.

\section{INTRODUCTION}

Modern industry plays the key role in the scenario of environmental pollution. Aquatic bodies are being overwhelmed with microbes and waste matter. Among toxic substances, heavy metal cause threatening to human health and ecosystem and may lead to a serious groundwater pollution problem Since, heavy metals are among the conservative pollutants Kaparapu et al. (2015). Walter et al. (2011) reported that, three kinds of heavy metals are of concern, including precious metals (such as: $\mathrm{Pd}, \mathrm{Ag}, \mathrm{Pt}, \mathrm{Ru}, \mathrm{Au}$ etc.), toxic metals (such as: $\mathrm{Hg}, \mathrm{Cr}, \mathrm{Pb}, \mathrm{Zn}, \mathrm{Cu}, \mathrm{Ni}, \mathrm{As}, \mathrm{Cd}, \mathrm{Sn}, \mathrm{Co}$, etc.) and radionuclides (such as: $\mathrm{U}, \mathrm{Ra}, \mathrm{Th}, \mathrm{Am}$, etc.). That are bio-accumulative and non-biodegradable toxins (Walter et al., 2011 and Prabha et al., 2016), the presence of such metals in aquatic environments cause severe damage to aquatic life, hence they find their way to the food chain (Hassan et al., 2013 and 2014; Brouersa et al., 2016) and as a result profoundly disrupting the biological processes. Moreover, heavy metals enter our bodies through eating, drinking, skin and inhaling (Renge et al., 2012), once in the body these metals have serious consequences on human such as nervous system deteriorations, reproductive failures, brain damage, irritability, kidney damage, anaemia, tumour formation, muscles weakness, etc (Bhatnagar and Kumari, 2013). Moreover, they also accumulate in the sediments and slowly released into the water body (Hassan et al., 2013 and 2014; Prabha et al., 2016).

Therefore, removal of heavy metals from discharged effluents has become important to maintain water quality that is suitable for human health and environment. Concerning remediation of harmful industrial effluent, various conventional methods have been employed in removal of heavy metals from aqueous industrial effluxents such as; membrane filtration, ion exchange, chemical precipitation, reverse osmosis, solvent extraction, electrodialysis, oxidation, evaporation, activated carbon adsorption (Pappalardo et al., 2010 and Brouersa et al., 2016). Nevertheless, those methods have extremely high potential in the removing of heavy metals, but often with high operational costs (Prabha et al., 2016) and difficult to maintain due insufficient to meet strict regulatory requirements, in addition to, extra cost for treating the resulting sludge. Hence, there is the insistence on innovative technologies with low cost, and high efficiency, for the removal of metal from contaminated industrial wastewater (Oilgae, 2010 and Brouersa et al., 2016).

Biosorption has been shown to be a feasible economically favourable alternative with high adsorptive capacities for the removing of heavy metals from wastewater (Bhatnagar and Kumari, 2013). Besides, it enhanced selectivity for specific metals of interest, reduced operation time, improved the removal effici-ency from diluted solutions, and minimization of chem-ical or biological sludge, so, no production of secondary compounds which might be toxic (Kaparapu et al., 2015). Simply, biosorption is an effective technology using living or dead biomasses to remove toxic metals from aqueous solutions (Davis et al., 2003 and Nirmal and Cini, 2012).

The mechanism of biosorption is mainly based on physical adsorption (electrostatic attraction-Vanderwaal forces of attraction) and/or chemical adsorption (covalent binding between negative charge of cell surface and cationic ions). Various biomasses such as bacteria, yea- 
st, fungi, plants and alga for biosorption of metal ions have been extensively studied in the last two decades (Vieira and Volesky, 2000). Among all the biological materials, marine algae have many features to be considered as an ideal candidates as biosorpent, including rich source in the oceanic environment, relatively cheap to process, able to accumulate high metal content and have high metal binding capacities due to the presence of hetero-polysaccharides, proteins or lipid in its cell wall structure for sequestration of heavy metal ions (Davis et al., 2003), high tolerance to heavy metals, and large surface area/volume ratios (Davis et al., 2003 and Bhatnagar and Kumari, 2013), beside all of that it is ecologically safer way. The commercial use of algal cultures spans about 75 years with application to wastewater treatment and mass production of different strains such as Chlorella and Dunaliella (Abdel-Raouf et al., 2012).

Algae are significantly effective in treating more than one problem at a time, which is not possible by a conventional process of chemical treatment (Bhatnagar and Kumari, 2013). Qari and Hassan (2014) reported that Dunaliella sp. has removed $95 \%$ of $\mathrm{Zn}$ and Cd after 108 hours, and $90 \%$ of $\mathrm{Cu}$ after 60 hours of incubation. Moreover, $93 \%$ of $\mathrm{Pb}, \mathrm{Ni}$ and $\mathrm{Cr}$ were removed after 36 hours of incubation. However, concerning Ulva lactuca Ghoneim et al. (2014) mentioned that the dead biomass of the green alga Ulva lactuca could be used as an efficient biosorpent material for the removal of heavy metals ions from aqueous solutions. Further, green algal species like Scenedesmus quadricauda, Chlorella vulgaris (Awasthi and Rai, 2004) and Chlorella homosphaera (Nirmal et al., 2010) have also been tested for their biosorption capacities.

Suez Gulf has a unique geographic location, where it is ended with Suez Canal. This canal is a vital navigational passage way linking between the Mediterranean and the Red Sea and then connects between east and west. In this area, a large number of industries were created and discharged wastes containing different compound including heavy metals (Ghoneim et al., 2014) leading to serious environmental and public health problems. On the other hand, the discharged effluent contains high loads of organic pollutants which enhance flourishing of green seaweed causing another coastal environmental problem of eutrophication along shorelines. When the coast becomes covered with algae especially Ulva making a green mat called "Green Tide', the landscape becomes bad with a disgusting odour generated from rotten algae. The green tide is a serious environmental problem in coastal areas. Currently, the enormous amount of algal biomass presents a significant problem in waste disposal. Therefore, the development of a technology which effectively utilizes algae biomass is desired. Kaparapu et al. (2015) have noted the applicability of algal biomass as a biosorpents

The present work focused on, how one of those problems can solve the other. In this context, two of the most dominant and commonly blooming marine green algae in Suez Gulf are used as biosorpent for heavy metals in the industrial effluent. Hence, to be a applicable, the present study investigated the biosorption performance and efficiency of non-living dried biomass obtained from the local blooming of the green unicellular microalgae; Dunaliella salina and the green seaweed; Ulva lactuca to remove heavy metals $(\mathrm{Zn}, \mathrm{Cu}, \mathrm{Cd}, \mathrm{Fe}, \mathrm{Mn}$, $\mathrm{Pb}, \mathrm{Cr}$ and $\mathrm{Ni}$ ) from two different types of aqueous industrial effluents, one for petrochemicals and the other for fertilizers production. Beside of that, the choice of this species was based on its availability and cost.

\section{MATERIALS AND METHODS}

\section{Preparation of Adsorpents Biomass}

Two species of the most frequent and common green alga inhabiting Suez Gulf, a northern part of the Red Sea, were selected to use as adsorbents agent. One of them, Ulva lactuca, is macro-green alga and the other Dunaliella salina is unicellular green phytoplankton.

\section{Preparation of Ulva lactuca}

The marine macroalgae Ulva lactuca was collected from the intertidal zone Suez Gulf at Suez governorate, Egypt in the beginning of spring season (at the end of March 2016). Where Ulva lactuca was always flourished and give a blooming growth during that period of the year at Suez Gulf (Fig. 1). The collected algal biomass which used in its natural forms was washed several times with excess tap water and finally with distilled water in order to remove sand, impurities, and salt from the surface. The washed algal biomass air-dried for four days and then was oven dried for $48 \mathrm{~h}$ at $60^{\circ} \mathrm{C}$.
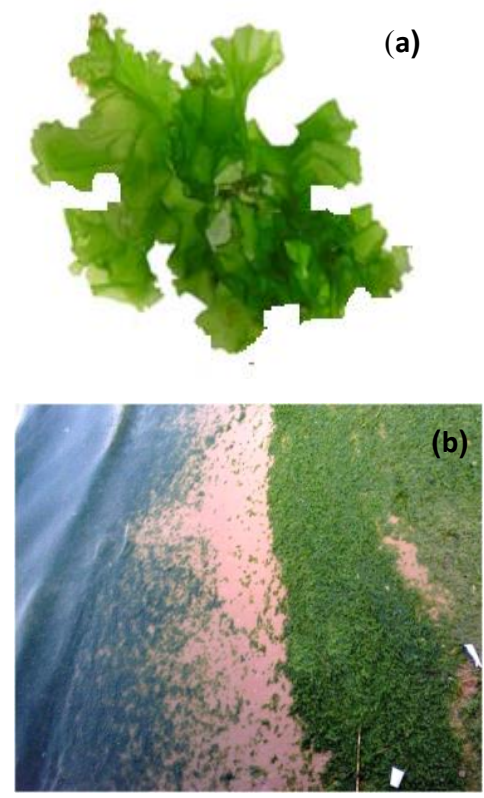

Figure (1): (a) Ulva lactuca (b) blooming growth at the intertidal zone Suez Gulf.

\section{Preparation of Dunaliella salina}

The marine unicellular green microalgae Dunaliella 
Salina was collected from Suez Gulf and from two small saline lakes near the Gulf in Egypt (Fig. 2) during summer season (at the mid of July 2016). The alga was harvested and rinsed several times with deionized water by centrifugation (5000rpm for 20min) to remove impurities and salts. Algal biomass pellets were then dried at $60^{\circ} \mathrm{C}$ until a constant weight was achieved (Vijayaraghan et al., 2005). The dry weight of the algal biomass was estimated from the average of at least three representative samples.
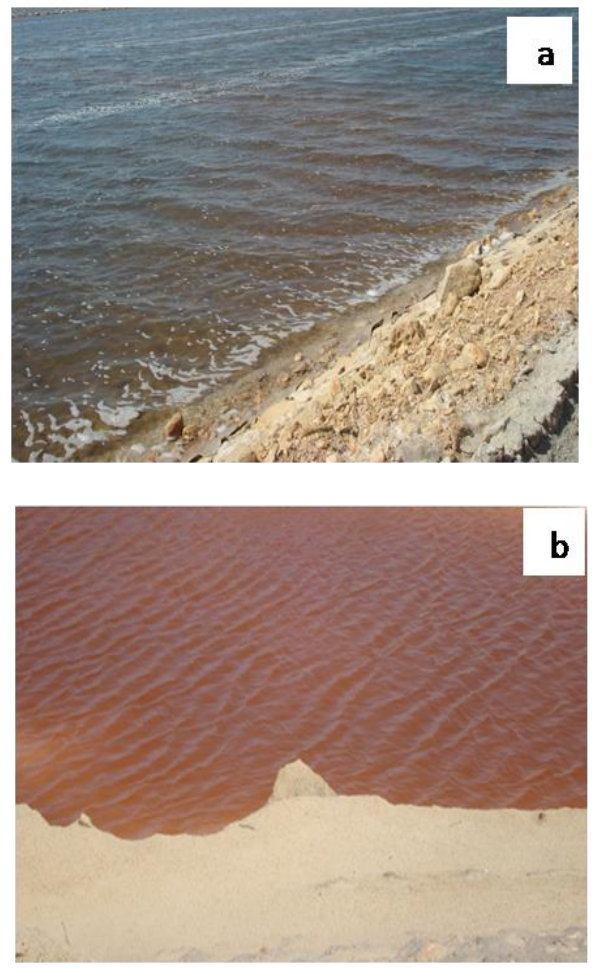

Figure (2): Dunaliella salina blooming at the intertidal zone of Suez Gulf (a) and saline lake (b).

\section{Industrial wastewater}

Two aqueous industrial effluents belonging to different industries; one from petrochemical (E.1) and the other from fertilizer industries (E.2) discharged their wastewater in Suez Gulf were collected in polyethylene containers. The collected samples were filtered through $\mathrm{GF} / \mathrm{C}$ glass filter paper and stored in dark at $4^{\circ} \mathrm{C}$. The Initial heavy metal concentration within each effluent was determined. The $\mathrm{pH}$ was adjusted at 5 by using $0.1 \mathrm{M} \mathrm{NaOH}$ and $0.1 \mathrm{M} \mathrm{HCl}$ solutions; where $\mathrm{pH} 5$ reported being the optimum $\mathrm{pH}$ for heavy metal removal (Sweetly et al., 2014).

\section{Adsorption Experiment}

The adsorption experiments were carried out in batch mode, in a $250 \mathrm{ml}$ conical flask containing; $100 \mathrm{ml}$ of wastewater; $1 \mathrm{~g}$ of the adsorbent was added. The mixture was agitated on mechanical shaker (at $250 \mathrm{rpm}$ ) for $180 \mathrm{~min}$, with designed intervals period of $30,60,90$, 120, 150 and $180 \mathrm{~min}$. The $\mathrm{pH}$ adjusted at 5 and tem- perature at $25^{\circ} \mathrm{C}$ before adding adsorbent. After that, 5 $\mathrm{ml}$ of each mixture was centrifuged for 15 minutes at a speed of $5400 \mathrm{rpm}$ to separate the supernatants from the adsorbent. Control for heavy metals without addition of adsorbent was also maintained. The residual concentration of the tested heavy metals $(\mathrm{Cd}, \mathrm{Zn}, \mathrm{Cu}, \mathrm{Mn}, \mathrm{Pb}$, $\mathrm{Fe}, \mathrm{Cr}$ and $\mathrm{Ni}$ ) in the supernatant was determined using atomic absorption (Hashim and Chu, 2004; Ajaykumar et al., 2008). The percentage removal and metal uptake efficiencies (Biosorption, \%) of all adsorbents were determined with following expressions (Zhang et al., 1998; Hashim and Chu, 2004):

$$
\text { Biosorption }(\%)=(\mathrm{Ci}-\mathrm{Cf}) / \mathrm{Ci} \text { X } 100
$$

The amount of metal adsorbed, Q (mg metal/gram absorbent) was computed using the following equation (Chen, 2005):

Where,

$$
\mathrm{Q}=(\mathrm{Ci}-\mathrm{Cf}) \mathrm{V} / \mathrm{m}
$$

$\mathrm{Q}=$ Amount of metal adsorbed $(\mathrm{mg} / \mathrm{g})$

$\mathrm{Ci}=$ Initial metal concentration in solution $(\mathrm{mg} / \mathrm{l})$

$\mathrm{Cf}=$ Final metal concentration in supernatant after adsorption $(\mathrm{mg} / \mathrm{l})$

$\mathrm{V}=$ Volume of solution $(\mathrm{ml})$

$\mathrm{m}=$ Mass of the adsorbent $(\mathrm{g})$.

\section{Statistical analysis}

All the biosorption experiments were conducted in triplicates to substantiate the results. The data shown are the mean values of three replicate determinations. One way ANOVA was applied to log-obtained data (Anonymous, 1993). Cluster analysis was performed using the MVSP program, where it is a multi-dimensional analysis classify the data into partition or division of a set and then into subsets (Legendre and Legendre, 1998) to clarify the similarity between heavy metals, algal species and effluents. Multivarate analysis of Canonical correspondence analysis (CCA) and Detrended Correspondence Analysis (DCA) Ordinations were performed using the CANOCO program version 2.1, according to Ter-Braak (1988) to elucidate the relations between the heavy metals and algal species, where the axes are constrained to optimize their relationship them.

\section{RESULTS}

The heavy metals (Cd, $\mathrm{Pb}, \mathrm{Zn}, \mathrm{Ni}, \mathrm{Cr}, \mathrm{Cu}, \mathrm{Fe}$ and $\mathrm{Mn}$ ) concentrations $\left(\mathrm{mg} . \mathrm{1}^{-1}\right)$ in the two industrial effluent of petrochemicals (E.1) and fertilizers (E.2) industry were cited in table (1). As it was illustrated in figure (3) it is clear that, the biosorption capacity of $D$. salina for $\mathrm{Cd}$, $\mathrm{Zn}$ and $\mathrm{Pb}$ was at its maximum level, especially in case of lead (22.34 mg.g $\left.{ }^{-1}\right)$ within petrochemical effluent during the entire period of the investigation showing a distinct gap, where it gave $7.63 \mathrm{mg} \cdot \mathrm{g}^{-1}$ after the same period within the fertilizer effluent. Zinc occupies the second position after lead (12.1 mg. $\left.\mathrm{g}^{-1}\right)$ within the same effluent. In this context, the biosorption capacity of $D$. 
salina for Cd was fluctuated in narrow range $(0.81$ to
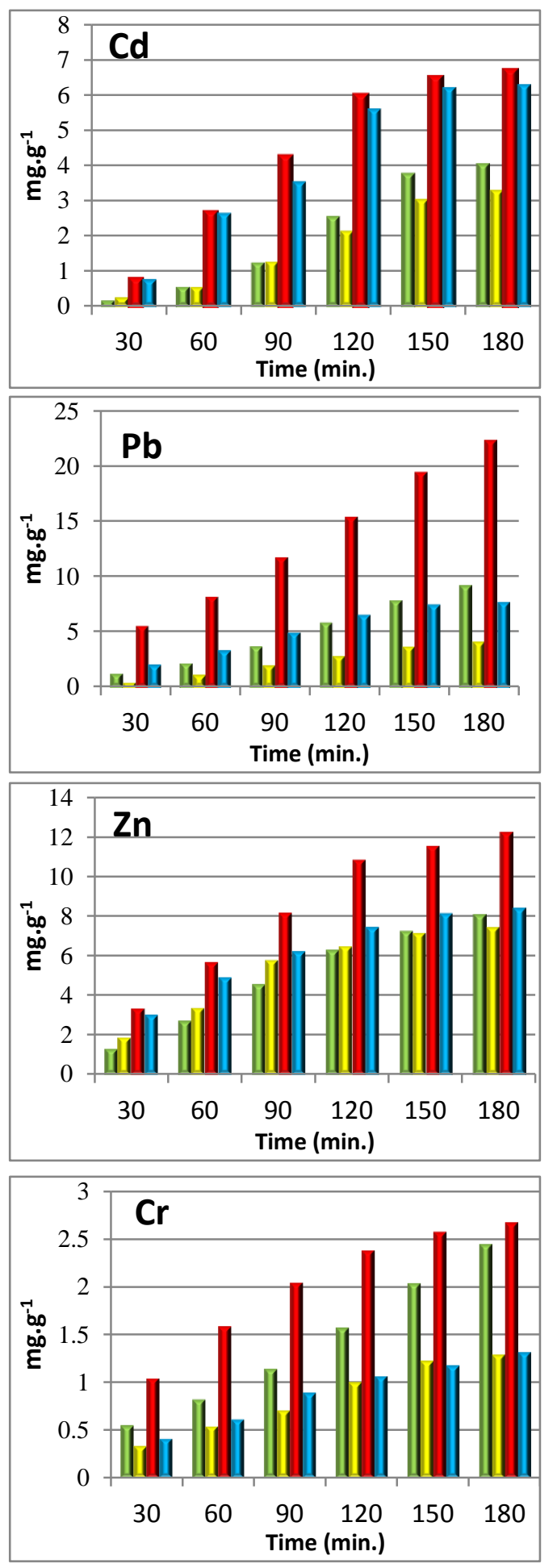

QU. lactucaE. 1

QU. lactuca E. 2

$6.73 \mathrm{mg} \cdot \mathrm{g}^{-1}$ and from 0.79 to $6.32 \mathrm{mg} \cdot \mathrm{g}^{-1}$ within petrochemical and fertilizer effluent respectively).
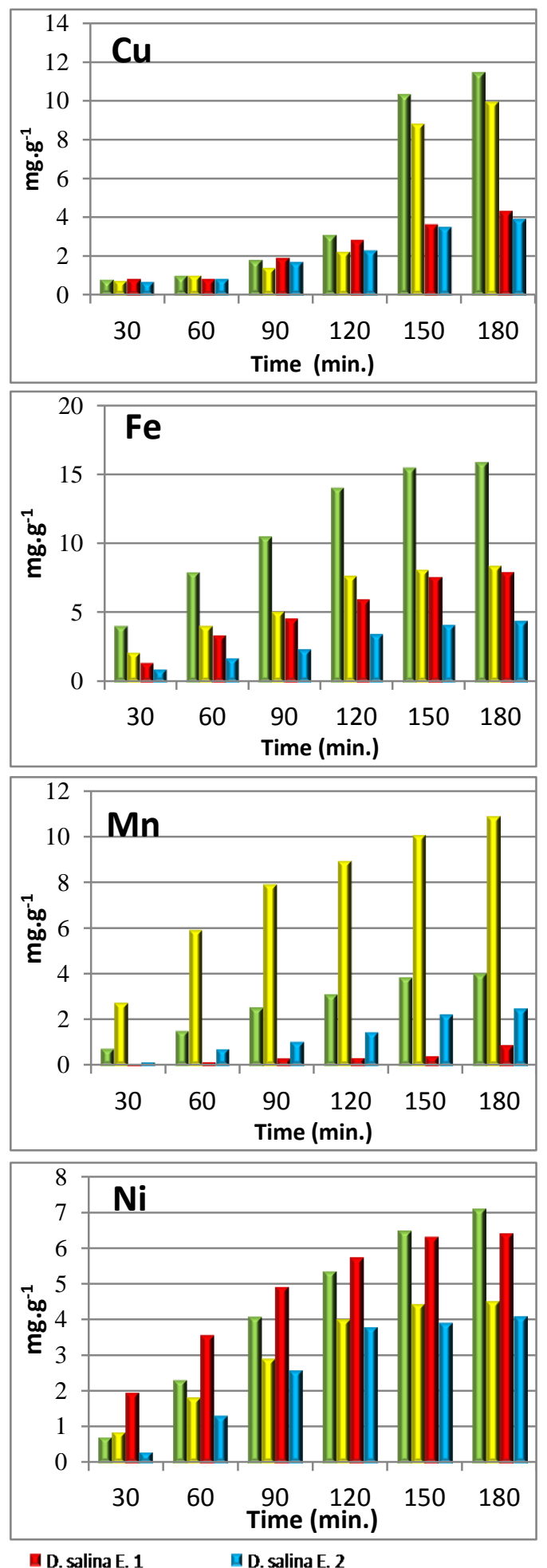

Figure (3): The amount of metal adsorbed $\left(\mathrm{mg}^{\mathrm{g}} \mathrm{g}^{-1}\right)$ by Ulva lactuca and Dunalliela salina in the two industrial wastewater containing heavy metals. (Where E1: petrochemical effluent and E2: fertilizer effluent). 
Mofeed, J.
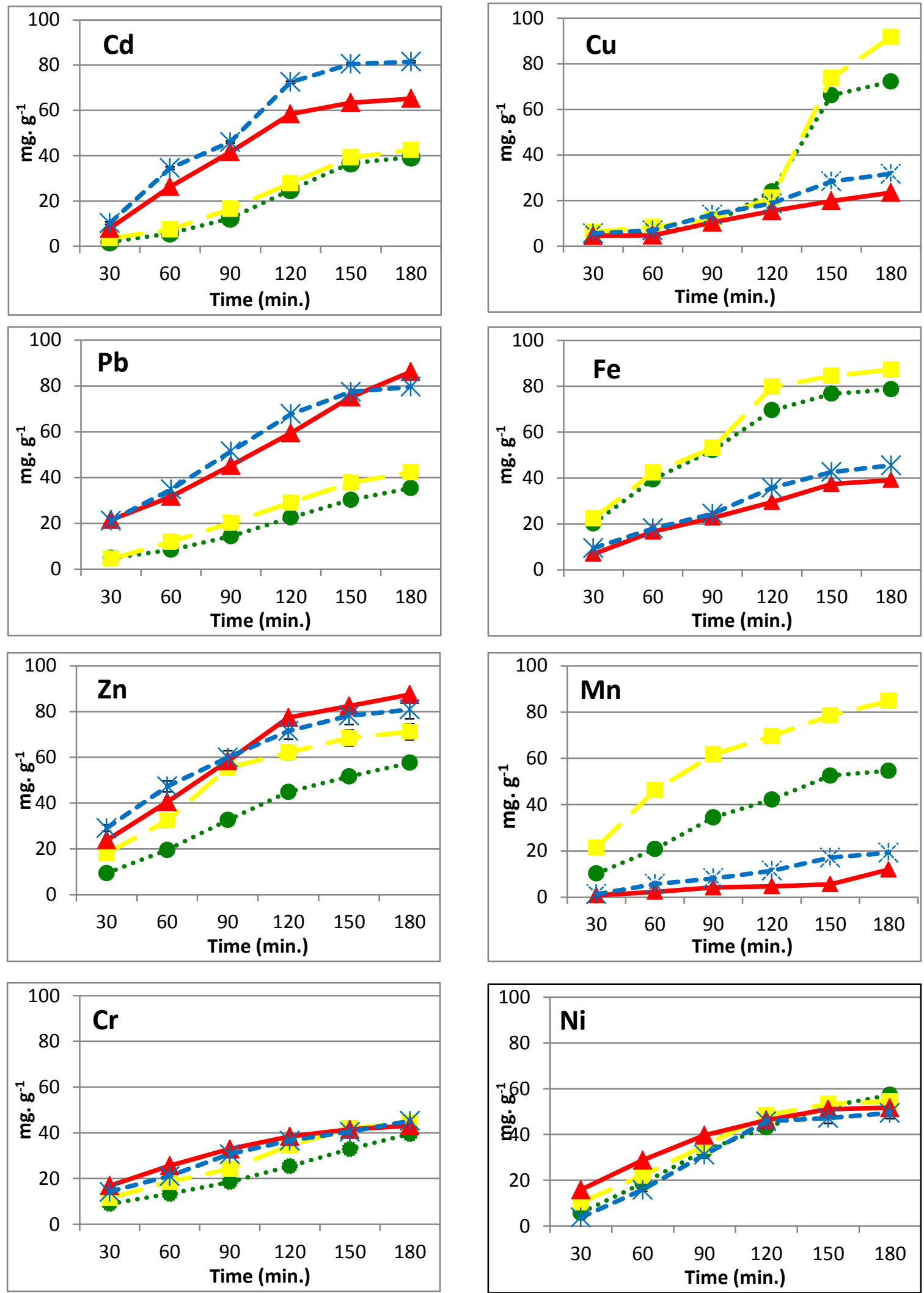

..•*U. lactuca E. $1 \square=$ U. lactuca E. $2 \longrightarrow$ D. salina E. $1-* *-$ D. salina E. 2

Figure (4): The biosorption efficiency (\%) of Ulva lactuca and Dunalliela salina in the two industrial wastewater containing heavy metals. (Where E1: petrochemical effluent and E2: fertilizer effluent). 
Table (1): Heavy metals concentrations $\left(\mathrm{mg} \mathrm{L}^{-1}\right)$ in the two industrial effluents. (Where E1: Petrochemical effluent and E2: Fertilizer effluent).

\begin{tabular}{l|llllllll}
\hline \hline \multicolumn{7}{c}{ Heavy metals } \\
\hline Effluent & Cd & Pb & Zn & Ni & Cr & Cu & Fe & Mn \\
\hline E. 1 & 10.33 & 25.91 & 14.04 & 12.41 & 6.2 & 18.48 & 20.18 & 7.32 \\
E. 2 & 7.76 & 9.58 & 10.41 & 8.26 & 2.9 & 12.31 & 11.59 & 12.86 \\
\hline
\end{tabular}

On the other hand, $U$. lactuca was the most efficient absorbent in case of $\mathrm{Cu}, \mathrm{Fe}$ and $\mathrm{Mn}$. Among this, it gave the maximum biosorption capacity within petrochemical effluent (E.1) for $\mathrm{Fe}\left(4.07-15.86 \mathrm{mg} . \mathrm{g}^{-1}\right)$ and $\mathrm{Cu}(0.83$ $\left.-11.49 \mathrm{mg} \cdot \mathrm{g}^{-1}\right)$ during the entire period of investigation. However it gave its maximum $\left(2.75-10.9 \mathrm{mg} \cdot \mathrm{g}^{-1}\right)$ within the fertilizer effluent with significant capacity in case of $\mathrm{Mn}$. It is of interest to mention that, talking about $\mathrm{Cr}$ and $\mathrm{Ni}$ will take another direction, where the controlling factor appear not to be the biosorbent species or the heavy metal itself, but it was the type of industrial effluent. Where, for both heavy metals (Ni and $\mathrm{Cr}$ ) the biosorption capacity of the two tested species gave its maximum with in fertilizer effluent (E2) during the entire period of the investigation with superiority of $D$. salina in case of Chromium.

Anent the percentage of removal efficiencies of all adsorbents "Biosorption (\%)", the recorded results (Fig. 4) reveal that Cadmium by Ulva lactuca and Dunalliela salina reach its maximum $(10.2 \%$ after 30 min. $-81.5 \%$ after $180 \mathrm{~min}$.) by $D$. salina within E2 followed by the E.1. While the biosorption of cadmium by U. lactuca had lower rang within both petrochemicals $(1.8 \%$ after 30 min. - $39.3 \%$ after 180 min.) and fertilizer $(3.58 \%$ after 30 min. - $42.5 \%$ after 180 min.) effluents. Again, the ability of $U$. lactuca to remove $\mathrm{Pb}$ was lower than that of $D$. salina, where its maximum efficiencies did not exceed $42.3 \%$ and $35.4 \%$ in the fertilizer and petrochemicals effluents respectively after $180 \mathrm{~min}$.

It is noticeable that, there was a large gap between the biosorption efficiency of $D$. salina and that of $U$. lactuca, with superiority of $D$. salina over $U$. lactuca. In this context, again $D$. salina was more effective in bioremoval of Zinc from both petrochemicals (87.4\% after $180 \mathrm{~min}$.$) and fertilizer (80.9 \% after 180 \mathrm{~min}$. effluent than $U$. lactuca, however, the minimum Zinc biosorption efficiency was recorded in case of $U$. lactuca within petrochemicals effluent $(57.6 \%$ after 180 $\min )$.

Compared to the previous results, U. lactuca had the superiority in the uptake efficiencies of $\mathrm{Mn}, \mathrm{Fe}$ and $\mathrm{Cu}$ over D. salina As shown in figure (4), the maximum Manganese $(\mathrm{Mn})$ biosorption efficiency $(84.8 \%$ within fertilizer effluent and $54.6 \%$ within petrochemical effluent) was recorded by using $U$. lactuca. However, low range of $\mathrm{Mn}$ biosorption efficiency (19.2\% within fertilizer effluent and $11.9 \%$ within petrochemicals effluent) was recorded by using $D$. salina. At the same time and by the same trend, $U$. lactuca had the sovereignty over $D$. salina in their biosorbtion ability of ferric (Fe) from both fertilizers effluent (87.2\%) and petrochemicals effluent (78.6\%). A glance on figure (4) reveled that, the biosorption of copper $(\mathrm{Cu})$ from the two types of effluent and by using the two algal species showed compatible efficiency during the first 120 minutes $(15.4-18.7 \%)$. While the results reflect a great jump in the copper biosorption ability by using $U$. lactuca after infect the 120 minutes barrier, where it reaches its maximum $(91.8 \%$ in fertilizer effluent and $72.2 \%$ in petrochemicals effluent) after 180 minutes.

It is worth mentioning that, the uptake efficiencies of both Nickel $(\mathrm{Ni})$ and Chromium $(\mathrm{Cr})$ by the two tested species within both types of industrial effluents was tight and uneven without fixed trend giving its maximum (57.3 - 49.4\%) for Nickel after 180 minutes. The same phenomenon was recorded to Chromium $(\mathrm{Cr})$, which fluctuated from $39.5 \%$ (by using U. lactuca) and $46.1 \%$ (by using $D$. salina as biosorping agent) within the fertilizer effluent; however petrochemical effluent was more or less affected.

Regarding cluster analysis (Fig. 5) reflect the similarity between the biosorption of tested heavy metals, where $\mathrm{Mn}, \mathrm{Fe}$ and $\mathrm{Cu}$ were grouped in one group with noticeable higher similarity between $\mathrm{Fe}$ and $\mathrm{Mn}$, which grouped in minor subgroup. On the other hand $\mathrm{Pb}$ and $\mathrm{Cd}$ were grouped in minor subgroup which related with less similarity with $\mathrm{Zn}$. However $\mathrm{Ni}$ and $\mathrm{Cr}$ were grouped together but with high dissimilarity. Beside the mentioned, inspection of ordination diagram produced by the Canonical Correspondence Analysis (CCA) showed the relation between biosorption of tested heavy metals and the tested species. A glance of (Fig. 6) described a noticeable relation between Ulva lactuca and $\mathrm{Mn}, \mathrm{Fe}$ and $\mathrm{Cu}$ uptake. Meanwhile, $\mathrm{Zn}, \mathrm{Pb}$ and $\mathrm{Cd}$ uptake were closely related with $D$. salina. It is of interest to mention that, $\mathrm{Ni}$ and $\mathrm{Cr}$ were grouped in separate intermediate group.

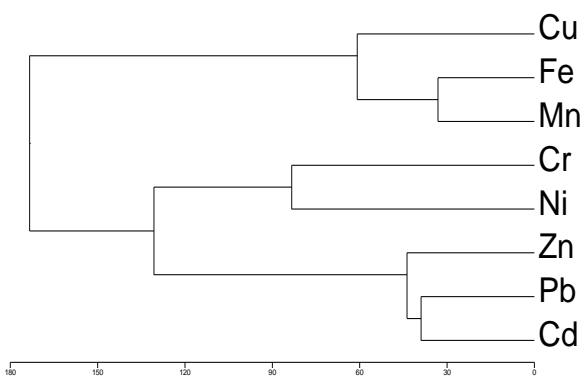

Figure (5): Dendrogram produced by the Cluster analysis of the tested heavy metals. 


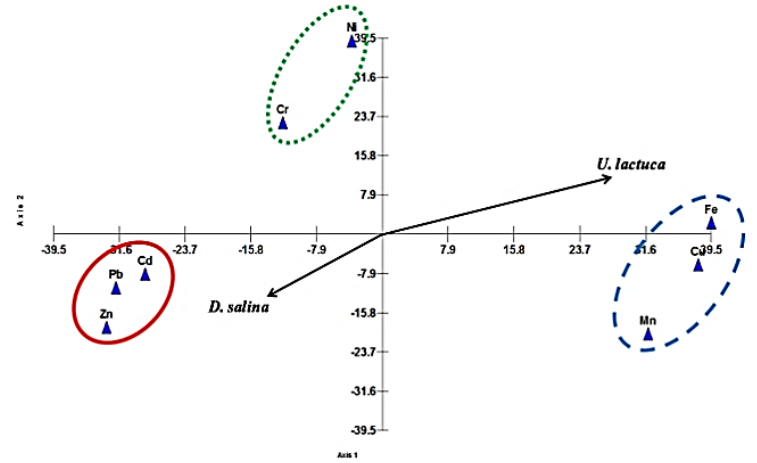

Figure (6): Canonical Correspondence Analysis (CCA) joint plot ordination diagram for correlation between algal species (arrow) and heavy metal ions.

\section{DISCUSION}

In developing countries, weak supervisions and inefficient implementation of laws for industry have caused rising pollution of water bodies. Hence, environmental pollution is currently one of the most important issues facing humanity, whether it is organic pollutants or containing heavy metals. Since, Suez Gulf suffer from troublesome bloom of Ulvala lactuca and Dunaliella salina beside the accumulation of heavy metals and there consequences problems, the effective utilization of this enormous algal biomass due to blooms become desired and very effective to solve the two serious coastal environmental and wastewater problems. The algal biomass considered as potential effective and cheap metal adsorbents for heavy metals removal. Biosorption of heavy metals from aqueous solutions is a relatively alternative technology for the treatment of industrial wastewater, which utilized naturally occurring materials derived from biomass (Kaparapu et al., 2015). Micro-algae have a remarkable ability to take up and accumulate heavy metals from their surrounding environment (Mishra et al., 2011). (Abdel-Raouf et al., 2012) also reviewed that, numerous species of algae (living and non-living cells) are capable of sequestering significant quantities of toxic heavy metal ions from aqueous solu-tions. Algal metal sequestering processes occur by diff-errent mechanisms. This can be dependent on the alga, the metal ion species, the solution conditions and whether the algal cells are living or nonliving.

Anent the cited results, it is clear that, the biosorption capacity of $D$. salina for $\mathrm{Cd}, \mathrm{Zn}$ and $\mathrm{Pb}$ was at its maximum level, especially in case of lead during the entire period of the investigation. Zinc occupies the second position after lead within the petrochemical effluent. While, the biosorption capacity of D.salina for $\mathrm{Cd}$ was fluctuated in narrow range within petrochemical and fertilizer effluent respectively. The results which agrees with Puranik and Paknikar (1997) who recorded that, the biosorption capacity of Dunalliela towards Cd, $\mathrm{Pb}, \mathrm{Zn}$ and $\mathrm{Cu}$ is higher than other elements. Renge et al. (2012) also reported that Dunaliella salina cells have high tendency for zinc, $\mathrm{Pb}$ and $\mathrm{Cd}$ accumulation, the lowest tendency was for $\mathrm{Ni}$. It is noticeable that, in case of $U$. lactuca there is no significant difference between the amount of metal adsorbed from the two types of effluents in case of $\mathrm{Zn}$ and $\mathrm{Cd}$. In this context, $U$. lactuca was the most efficient absorbent in case of $\mathrm{Cu}$, $\mathrm{Fe}$ and $\mathrm{Mn}$. where, it gives the maximum biosorption capacity within petrochemical effluent for $\mathrm{Fe}$ and $\mathrm{Cu}$ during the entire period of investigation. However, it gave its maximum within the fertilizer effluent in case of $\mathrm{Mn}$.

On the other hand, in case of $\mathrm{Cr}$ and $\mathrm{Ni}$ the controlling factor was the type of industrial effluent, was the biosorption capacity of the two tested species gave its maximum within fertilizer effluent during the entire period of the investigation with superiority of D.salina in case of Chromium Chopra and Pathak (2010) reported that, removal of $\mathrm{Ni}$ from single metal solutions by Chlorella vulgaris was more efficient than in mixture. The decrease in biosorption efficiency could be due to the interference between compounds and metals in mixture. Bulgariu and Bulgariu (2014) noted that, the biosorptive characteristics of marine Green algae (Ulva lactuca) have been investigated for the removal of $\mathrm{Cu}$, $\mathrm{Mn}$ and Co ions from an aqueous solution.

The uptake of Cadmium by Ulva lactuca and Dunalliela salina it reached its maximum by $D$. salina within fertilizer effluent followed by the petrochemical effluent, while the biosorption of cadmium by $U$. lactuca had lower range within both effluents. However, (Ghoneim et al., 2014) concluded that $U$. lactuca can be used as an effective, low cost, and environmentally friendly biosorbent for removal of $\mathrm{Cd}$ ions from aqueous solution. A more or less the same phenomenon was recorded in the uptake efficiencies of Lead $(\mathrm{Pb})$, where $D$. salina gave the maximum uptake of $\mathrm{Pb}$ from both types of tested effluents $(86.2 \%$ and $79.6 \%$ in fertilizers and petrochemical effluent respectively after 180 min.). Puranik and Paknikar (1997) recorded that, biosorption efficiency of Dunaliella towards $\mathrm{Zn}$ and $\mathrm{Cd}$ (95\%), $\mathrm{Pb}(93 \%)$ and $\mathrm{Cu}(90 \%)$ is higher than other elements $(\mathrm{Cr}$ and $\mathrm{Ni})$. In another study, Mendoza-Cozatl et al. (2006) recorded that, Euglena gracilis has high efficiency (80\%) for Cd removal by however, it was found to be less than the efficient for $\mathrm{Pb}$ by $15 \%$. The result which agree with our results where, the ability of $U$. lactuca to uptake $\mathrm{Pb}$ was lower than that of $D$. salina, where it's maximum uptake efficiencies did not exceed $42.3 \%$ and $35.4 \%$ in both effluents after 180 mins.

Dunaliella salina was more effective in bioremoval of Zinc from both effluents than $U$. lactuca. However, the minimum Zinc biosorption efficiency was recorded in case of $U$. lactuca within petrochemicals effluent. $D$. salina cells have high tendency for zinc accumulation, while the lowest tendency was for cadmium, this may be due to the importance of zinc as hydrogen transferring in photosynthesis. Generally, it has been reported that, Dunaliella sp. can tolerate high concentrations 
of toxic metabolites than most of the other phytoplankton (Shafik, 2008).

Ulvala lactuca had the superiority in the remove efficiencies for $\mathrm{Mn}, \mathrm{Fe}$ and $\mathrm{Cu}$ over $D$. salina. The results which supported by Ibrahim et al. (2016) who noted that, Ulva seaweed is a good biosorbent material for removing heavy metals. It is worth mentioning that, the uptake efficiencies of both Nickel (Ni) and Chromium $(\mathrm{Cr})$ by the two tested species within both types of industrial effluents was tight and uneven without fixed trend (Liu et al., 2014) indicated that, the algal biomass had a highly selective biosorption capacity for heavy metals, where the order of biosorption for heavy metals was $\mathrm{Fe}>\mathrm{Cr}>\mathrm{Ni}$.

Cluster analysis reflects a high similarity between the biosorption of $\mathrm{Mn}, \mathrm{Fe}$ and $\mathrm{Cu}$ and also between $\mathrm{Pb}, \mathrm{Cd}$ and $\mathrm{Zn}$. On the other hand $\mathrm{Ni}$ and $\mathrm{Cr}$ were grouped together but with high dissimilarity.

However, the ordination diagram produced by the Canonical Correspondence Analysis (CCA) showed noticeable relation between Ulva lactuca and $\mathrm{Mn}, \mathrm{Fe}$ and $\mathrm{Cu}$ removal. Meanwhile, $\mathrm{Zn}, \mathrm{Pb}$ and $\mathrm{Cd}$ removal were closely related with $D$. salina. While, $\mathrm{Ni}$ and $\mathrm{Cr}$ were grouped in separate intermediate group. Shanab et al. (2012) mentioned that, algae isolated from polluted water were found to be more tolerant to metal toxicity. Moreover, tolerance of algae to heavy metals differed among algal species. The difference in biosorption ability between algal species attributed to the cell surf-ace has several kinds of functional groups with varying affinity for an ionic species. Both low and high affinity functional groups are responsible for the sorption of metal ions at high and low concentrations of metal ions (Mehta and Gaur, 2001).

\section{CONCLUSION}

In conclusion, the most dominant and commonly blooming marine green algae" Ulva lactuca and Dunalliela salina in Suez Gulf can be utilized as biosorpent for heavy metals in the industrial effluent to solve both problems of eutrophication and heavy metals pollution. Both the green seaweed Ulva lactuca and the microalgae Dunalliela salina reflected a strong capability for selective biosorption of heavy metals from aqueous wastewater. This advanced technology is not only cheaper and more effective but also quick and easy to operate.

However, the comparison of the two algal genera revealed that they differed somewhat in their abilities to adsorb $\mathrm{Cd}, \mathrm{Pb}, \mathrm{Zn}, \mathrm{Ni}, \mathrm{Cr}, \mathrm{Cu}, \mathrm{Fe}$ and $\mathrm{Mn}$. Based on the obtained results, it can be concluded that the dried biomass of Dunaliella salina and Ulva lactuca has a relatively high affinity towards the heavy metal, particularly $\mathrm{Pb}, \mathrm{Zn}$ and $\mathrm{Cd}$ for Dunaliella salina and $\mathrm{Cu}$, $\mathrm{Fe}$ and Mn for Ulva lactuca. Moreover, the biosorbtion of heavy metals by algal species from aqueous solutions is a complex process, depending upon the algal species, the heavy metal ion, and the contributing source. So, deeper studies should be done in the future to determine the most efficient biosorpent species for every type of industrial waste. Actually, during solving the problem of heavy metals using blooming biomass of the local algae got rid of the problem of eutrophication. Therefore, biosorption of heavy metals by algal biomass is being strongly recommended as a powerful technique for the removal of heavy metals from various industrial polluted effluents.

\section{REFFERENCES}

ABDEL-RAOUF, N., A.A.AL-HOMAIDAN AND I.B. M. IBRAHEEM. 2012. Review: Microalgae and wastewater treatment. Saudi Journal of Biological Sciences, 19: 257-275.

AJAYKUMAR, A.V., S. AL HASHIMI, AND N. HILAL. 2008. Investigation of kinetics and mechanism involved in the biosorption of heavy metals on activated sludge. Int. J. Green Energy 5: 313-321.

ANONYMOUS. 1993. SPSS program for Windows. Base system user's Guide Release 5.0 SPSS INC.

AWASTHI, M. AND L.C. RAI. 2004. Adsorption of nickel, zinc and cadmium by immobilized green algae and cyanobacteria: A comparative study. Annals Microbiol., 54: 257-267.

BHATNAGAR, S., AND R. KUMARI. 2013. Bioremediation: A Sustainable Tool for Environmental Management. A Review. Annual Review and Research in Biology. 3(4): 974-993.

BROUERSA, F., J. TARIQ, AND M. AL-MUSAWIB. 2016. On the optimal use of isotherm models for the characterization of biosorption of lead onto algae. bioRxiv (In press).

BULGARIU, L., AND D. BULGARIU. 2014. Enhancing Biosorption Characteristics of Marine Green Algae (Ulva lactuca) for Heavy Metals Removal by Alkaline Treatment. J Bioprocess Biotech 4: 1-8.

CHEN, S. 2005. Bioremediation potential of spirulina: toxicity and biosorption studies of lead. J Zhejiang Univ. SCI, Biology. 6B (3): 171-174.

CHOPRA, A.K., AND C. PATHAK. 2010. Biosorption technology for removal of metallic pollutants-An overview .Journal of Applied and Natural Science 2 (2): 318-329.

DAVIS, A.T., B. VOLESKY, AND, A. MUCCI. 2003. A review of the biochemistry of heavy metal biosorption by brown algae. Water research 37: 43114330.

GHONEIM, M., S.H. EL-DESOKY, K. ELMOSELHY, A. ADEL, E.H. ABOU.ELNAGA, AND L. MOHAMEDEIN. 2014. Removal of cadmium from aqueous solution using marinegreen algae, Ulva lactuca. Egyptian Journal of Aquatic Research, 40: 235-242 
HASHIM, M.A., AND K.H. CHU. 2004. Biosorption of cadmium by brown, green, and red seaweeds. Chem. Eng. J. 97: 249-255.

HASSAN, I., J. BASAHI, I. ISMAIL, AND A. ZAHRAN. 2014. Effects of airborne heavy metal pollution on physiological and biochemical processes in lettuce (Lactuca sativa L. Romaine) Plants. Advances in Env. Biology), 25(3): 85-97.

HASSAN, I.A., J.M. BASAHI, AND I.M. ISMAIL. 2013. Gas exchange, chlorophyll fluorescence and antioxidants as bioindicators of airborne heavy metal pollution in Jeddah, Saudi Arabia. Current World Environment, 8(2): 203 -213.

IBRAHIM, W.M., A.F. HASSAN, AND A.Y. AZAB. 2016. Biosorption of toxic heavy metals from aqueous solution by Ulva lactuca activated carbon. Egyptian journal of basic and applied sciences 3: 241-249.

KAPARAPU, J., R.G. NARASIMHA, AND P. KRISHNA. 2015. Marine algae as biosorbents. J. Algal Biomass Utln. 6 (3): 16- 19.

LEGENDRE, P., AND L. LEGENDRE. 1998. Numerical ecology. Elsevier. Developments in environ-mental modelling,3. Elsevier Scientific Publ. Co., Amsterdam Netherlands 9: $419 \mathrm{p}$

LIU, X., D. BEYREND, G. DUR, S. BAN. 2014: Effects of temperature on life history traits of Eodiaptomus japonicus (Copepoda: Calanoida) from Lake Biwa (Japan). Limnology, 15: 85-97

MEHTA, S. K., AND P.G. JAI. 2001. Removal of Ni and $\mathrm{Cu}$ forms ingle and binary metal solutions by free and immobilized Chlorella vulgaris. European J. Protistology, 37: 261-271.

MENDOZA-CÓZATL, D.G., E. RANGEL GONZALEZ, AND R. MORENO AND SÁNCHEZ. 2006. MSimultaneous $\mathrm{Cd}^{2+}, \mathrm{Zn}^{2+}$ and $\mathrm{Pb}^{2+}$ uptake and accumulation by photosynthetic Euglena gracilis. Arch. Environ. Contam. Toxicol., 51: 521-528.

MISHRA, S.P., J. THIRREE, A.S. MANENT, B. CHABOT, AND C. DANEAULT. 2011. Ultrasound-catalyzed TEMPO-mediated oxidation of native cellulose for the production of nanocellulose: Effect of process variables. Bio Resources, 6(1): 121-143

NIRMAL K.J.I., RITA, N. KUMAR AND O. CINI 2010. Removal of heavy metals by biosorption using freshwater alga. Journal of Pure and Applied Sciences, 17: 028-034.

NIRMAL, K.J.I., AND O. CINI, 2012. Removal of heavy metals by biosorption using freshwater alga Spirogyra hyalina. J. Environ. Biol. 33: 27-31.

OILGAE, R. 2010. The definitive guide for algae fuel researchers Academic Edition Tamilnadu India.
PAPPALARDO, L., JUMEANF.AND N. ABDO. 2010. Removal of Cadmium, Copper, Lead and Nickel from aqueous Solution by White, Yellow and Red United Arab Emirates Sand America Journal of Environmental Sciences. 6(1): pp 41-4.

PRABHA, Y., S.K. SONI, G. SHARMITA, AND SONALB. 2016. Potential of Algae in Bioremediation of Wastewater Current Research Int $\mathbf{J}$ Curr.Microbiol. App. Sci, 5(2): 693-700

PURANIK, P.R., AND K.M. PAKNIKAR. 1997. Biosorptionof lead and zinc from solutions .using strep to verticillium cinnamoneum wastebiomass $\mathbf{J}$ Biotechnol. 55: 113-124.

QARI, H.A., AND I.A. HASSAN. 2014. Removal of pollutants from waste water .using Dunaliella algae. Biomed. Pharmacol. J., 7(1): 147151.

RENGE, V.C., S.V. KHEDKAR, AND S.V. PANDE. 2012. Removal of heavy metals from wastewater using low cost adsorbents: a review. Scientific Reviews and Chemical Communications, 2 (4): 580-584.

SHAFIK, M.A. 2008. Phytoremediation of Some Heavy Metals by Dunaliella salina. Global Journal of Environmental Research 2 (1): 01-11.

SHANAB, S., E. ASHRAF, AND E. SHALABY. 2012. Bio removal capacity of three heavy metals by some microalgae species (Egyptian Isolates). Plant Signaling and Behavior, 7(3): 1-8.

SWEETLY, D.J., K. SANGEETHA, AND B. SUGANTHI. 2014. Biosorption of Heavy Metal Lead from Aqueous Solution by Non-living Biomass of Sargassum myriocystum. International Journal of Application or Innovationin Engineering and Management, Volume 3(4): 39-45.

TER BRAAK, C.J.F. 1988. CANOCO-A FORTRAN program version 21 for. [Partial]. [Canonical] Correspondence Analysis Principal Component Analysis and Redundancy Analysis Agricultural Mathematics Group Report LWA-88-02, Wageningen 95 pp.

VIEIRA, R.H.S.F., AND .B. VOLESKY. 2000. Biosorptio: a solution to pollution? Int. Microbiol. 3 (1): 17-24.

VIJAYARAGHAVAN, K., J.R. JEGAN, K. PALANIVELU, AND M. VELAN. 2005. Copper removal from aqueous solution by marine green alga ulva reticula Electronic J. Biotecnol. 7(1): 22 -23.

WALTER, H.A., P.C. KANGAS, AND M. WALTER. 2011. Algalturf scrubbing cleaning surface water swit solar energy while producing a biofuel. BioScience 61 (6): 434-44.

ZHANG, W.X., Y.C. SHEN, L.I. SR. 1998. Epidemiological investigation on mental disorders in 7 areas of China. Chinese J Psychiatry, 31:69-77. 
الامتزار الحيوي للمعادن الثقيلة من المخلفات الصناعية السائلة بإستخدام الكتلة الحيوية الجافة لإثنين من

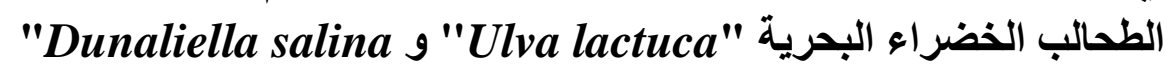

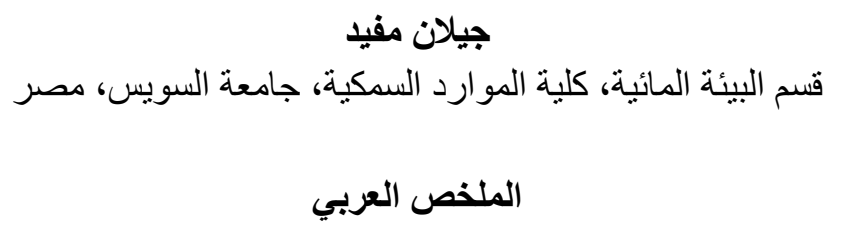

إن النهضة الصناعية المتز ايدة في منطقة خليج السويس تؤدي إلى مشكلتين بيئيتين خطيرتين، الاولي هي تلوث المياة بالمعادن

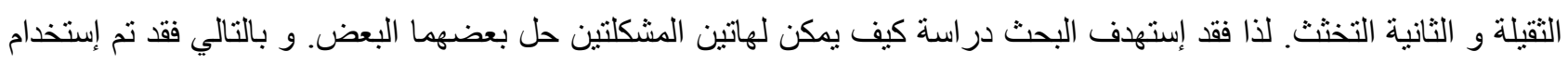

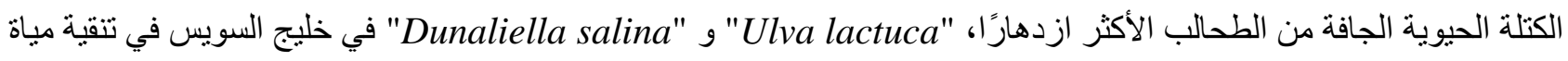

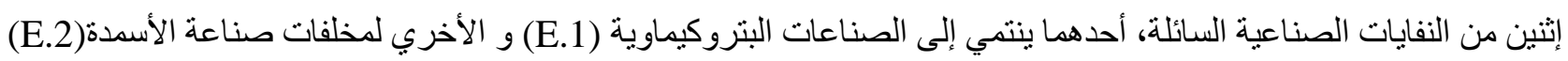

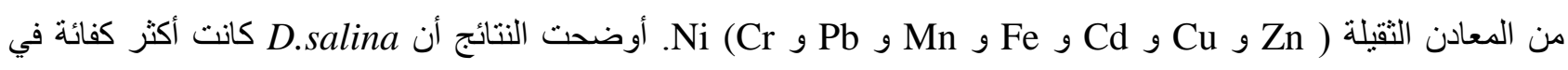

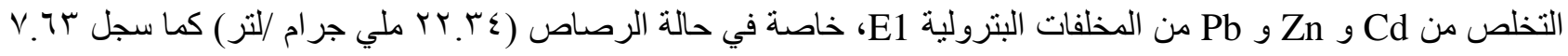

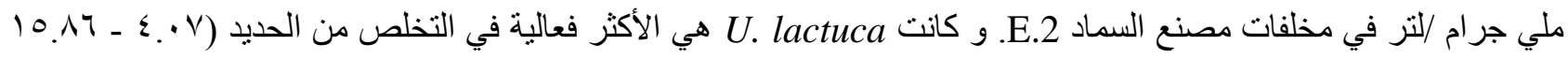

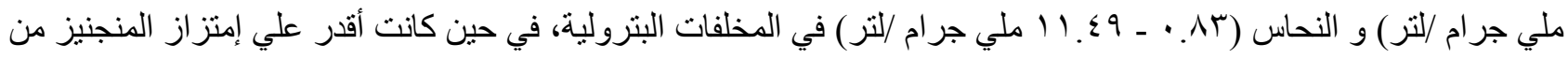

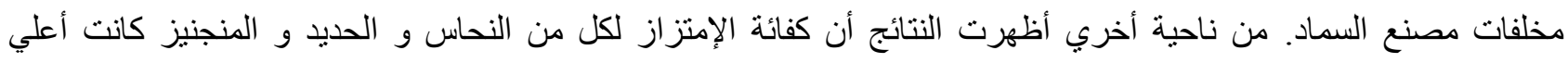

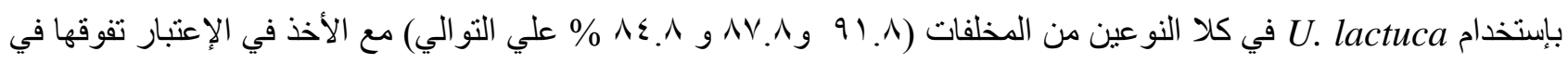

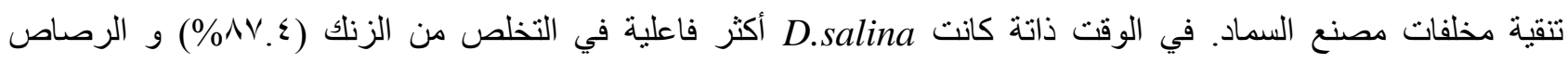

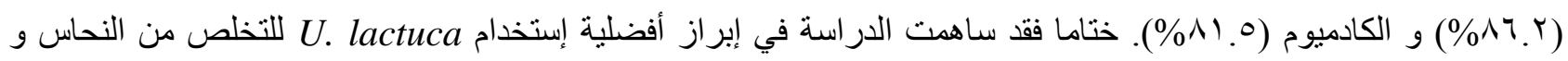

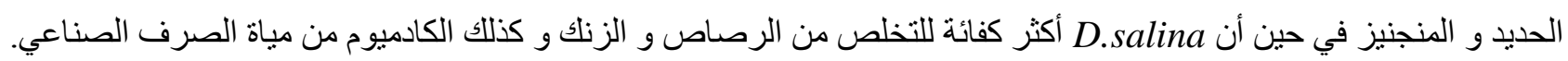

